\title{
THE
}

\section{Textiles from the Seventeenth-Century Privy at the Cross Street Back Lot Site}

Linda M. Welters

University of Rhode Island, Iwelters@uri.edu

Margaret T. Ordoñez

Follow this and additional works at: https://digitalcommons.uri.edu/tmd_facpubs

Terms of Use

All rights reserved under copyright.

\section{Citation/Publisher Attribution}

Ordonez, Margaret T. and Linda Welters. (1998). "Textiles From the Seventeenth-Century Privy at the Cross Start Back Lot Site." Historical Archaeology. 32(3):81-90.

Available at: http://www.jstor.org/stable/25616632

This Article is brought to you for free and open access by the Textiles, Fashion Merchandising and Design at DigitalCommons@URI. It has been accepted for inclusion in Textiles, Fashion Merchandising and Design Faculty Publications by an authorized administrator of DigitalCommons@URI. For more information, please contact digitalcommons-group@uri.edu. 


\section{SOCIETY for HISTORICAL ARCHAEOLOGY}

Textiles from the Seventeenth-Century Privy at the Cross Street Back Lot Site Author(s): Margaret T. Ordoñez and Linda Welters

Source: Historical Archaeology, Vol. 32, No. 3, Perspectives on the Archaeology of Colonial Boston: The Archaeology of the Central Artery/Tunnel Project, Boston, Massachusetts (1998), pp. $81-90$

Published by: Society for Historical Archaeology

Stable URL: http://www.jstor.org/stable/25616632

Accessed: 10/07/2013 12:49

Your use of the JSTOR archive indicates your acceptance of the Terms \& Conditions of Use, available at http://www.jstor.org/page/info/about/policies/terms.jsp

JSTOR is a not-for-profit service that helps scholars, researchers, and students discover, use, and build upon a wide range of content in a trusted digital archive. We use information technology and tools to increase productivity and facilitate new forms of scholarship. For more information about JSTOR, please contact support@jstor.org. 


\section{Textiles from the Seventeenth- Century Privy at the Cross Street Back Lot Site}

\section{ABSTRACT}

A variety of textiles came from the excavation of a 17thcentury privy behind the Nanny House site on Cross Street, Boston, Massachusetts. The largest group of fragments is silk fabrics and ribbons, valuable since cloths of this fine fiber have not survived in other 17th-century New England archaeological sites. Comparison of the fine wool textiles from Boston with coarse wool fabrics used by the Mashantucket Pequot Indians in Connecticut and Narragansett Indians in Rhode Island reveal distinct differences in quality. Fabrics made from a combination of silk and wool, cotton, or linen show the variety of mixtures that were available for those who could afford them. Negative pseudomorphs of cotton and bast fibers preserved evidence of cellulosic products in a mineralized form previously unreported in New England. The family that lived at this site used high quality fabrics with expensive weaves, mixtures, and fancy trims representing fashionable 17 th-century dress.

\section{Introduction}

The textiles from the Boston Central Artery/ Tunnel Project Cross Street Backlot site (BOSHA-13) are the first 17th-century archaeological textiles from a Colonial New England city to be available for study (Ordoñez and Welters 1995). The 161 fragments provide graphic evidence of textiles described in primary sources and costume histories. Representing a wide variety of 17 thcentury textiles, fragments came from 82 different fabrics and 20 yarns. Classifications are listed in Table 1 and discussed by section. Table 2 shows the distribution of the textiles in the privy. Silk filaments make up fabrics, threads, and ribbons. Thirteen different wool fabrics are quite varied. Some of the most interesting fabrics are mixtures of silk with wool, silk mixed with another fiber which has degraded, and mineralized cotton fabrics and bast yarns.
The woven silk fabrics which compose the largest group of fragments represent all six Harris Number strata (Heck and Balicki, this volume) in which textiles occurred. Two-thirds of the silk fabrics are unbalanced plain weaves with a higher number of warp yarns than weft. This imbalance plus the large size of the filling yarns produces a horizontal rib. The prominence of this rib varies from slight to pronounced and is the characteristic that helps tie contemporary names to the fabrics. Many of the silk fabrics are taffeta, often used for women's gowns, hoods, and aprons (Figure 1). Merchants in the 17th century called such high gloss silks, lustring (Kerridge 1985:129-130).

TABLE 1

FEATURE 4 DISTRIBUTION OF FABRIC TYPES AND YARNS

Fabrics

Silk Fabrics Total

Unbalanced Plain Weave23

Balanced Plain Weave

Satin Weaves

Silk Ribbons

Plain Weave

Satin \& Complex Weave5

Edge Bindings

Other Silk Constructions

Leno Weave

Knit

Bobbin Lace

Wool Fabrics

Plain Weave

Twill

Mixture

Silk \& Wool

Silk \& Cellulose (cellulose missing)

Cotton Fabrics

35

Yarns

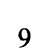

3

22

15

Silk-Separate

Silk-Sewn in a Fabric ${ }^{\mathrm{a}}$

Metal \& Silk

Bast

2

3

1

1

1

14

7

7

6

3

3

2

20

16

attached to fabrics; not separate yarns 


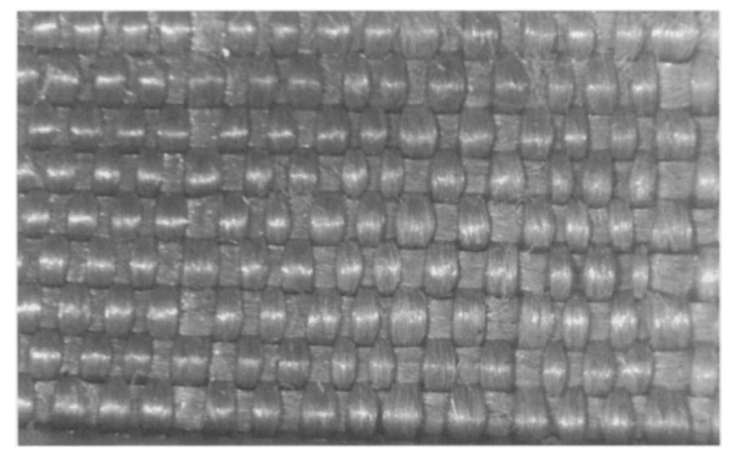

FIGURE 1. Silk taffeta, 56 warps and 28 wefts per centimeter, fragment $6747 / 38,032$.

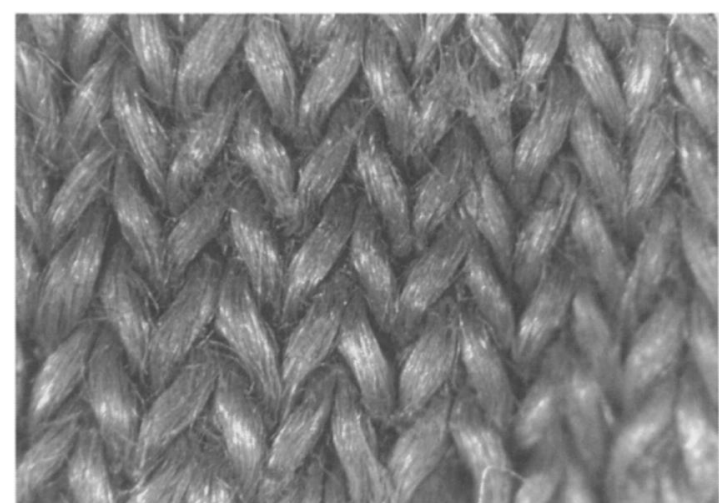

FIGURE 3. Silk plain knit, 10 loops per centimeter, fragment $6660 / 38,031 \mathrm{~A}$.

TABLE 2

DISTRIBUTION OF FABRIC TYPES AND YARNS BY HARRIS NUMBER

\begin{tabular}{|c|c|c|c|c|c|c|c|}
\hline \multirow[b]{2}{*}{ Fabrics } & \multicolumn{4}{|c|}{ Harris Number } & \multirow[b]{2}{*}{$\underline{151}$} & \multirow[b]{2}{*}{$\underline{154}$} & \multirow[b]{2}{*}{ Total } \\
\hline & 100 & 146 & 148 & 149 & & & \\
\hline Silk Fabrics & 4 & 28 & 2 & 2 & 1 & 1 & 38 \\
\hline Sewing Yarns & 2 & 16 & & & & & 18 \\
\hline Silk Ribbons & & 13 & 1 & 2 & & 6 & 22 \\
\hline Wool Fabrics & & 9 & & 5 & & & 14 \\
\hline Mixtures & 2 & 4 & & & & & 6 \\
\hline Cotton Fabrics & 1 & 1 & & & & & 2 \\
\hline Bast Yarns & 1 & 1 & & & & & 2 \\
\hline Total & 10 & 72 & 3 & 9 & 1 & 7 & 102 \\
\hline
\end{tabular}

Note: Analysis of 161 fragments allowed pieces of similar fiber content and construction to be grouped as one type of fabric.

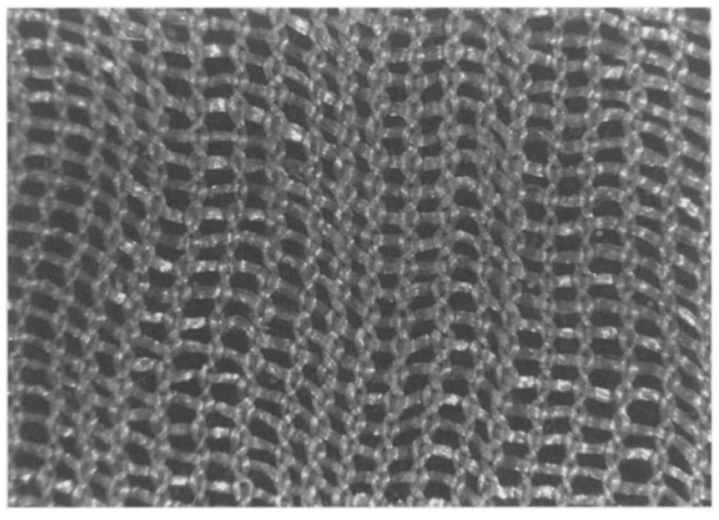

FIGURE 2. Silk gauze, 23 pairs of warp yarns per centimeter, fragment 6550/38,007A.
Most of this large group of silk fragments are plain weaves; three contain satin-woven stripes which provided variety to fabrics. Single yarns with a very low amount of spin compose most of the fabrics; since silk is a continuous filament, yarns do not need to be twisted to keep short fibers together as with wool and cotton. Lowtwist silk yarns produce lustrous fabrics; although plain weaves are less glossy than satin weaves, they would have been more durable because of their construction and would have matched the cultural values of the Puritan colony better than more opulent satins.

Another type of silk fabric from the privy is a leno weave fragment, which is characterized by 


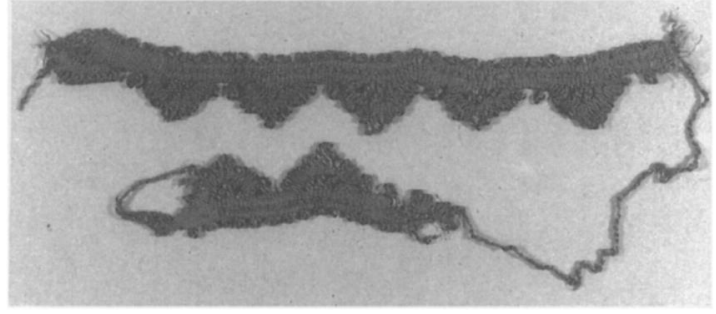

FIGURE 4. Bobbin lace made of 2-ply silk yarns, fragment $6611 / 38,120$.

crossed warps (Figure 2). Such light-weight fabrics were known as gauze or tiffany. Canterbury Walloon weavers in England claimed to have invented the fabric in the early 17th century (Kerridge 1985:127; Trautman 1989:53).

One small filling-knit fragment is most likely from a stocking (Figure 3). Both men and women of the gentry wore silk stockings, which could have been either woven or knitted of silk, wool, or cotton yarns. Woven stockings, a holdover from the medieval period, still were worn by the lower orders in the 17th century, whereas silk knit stockings were possessions of the wellto-do (Trautman 1989:57, 61).

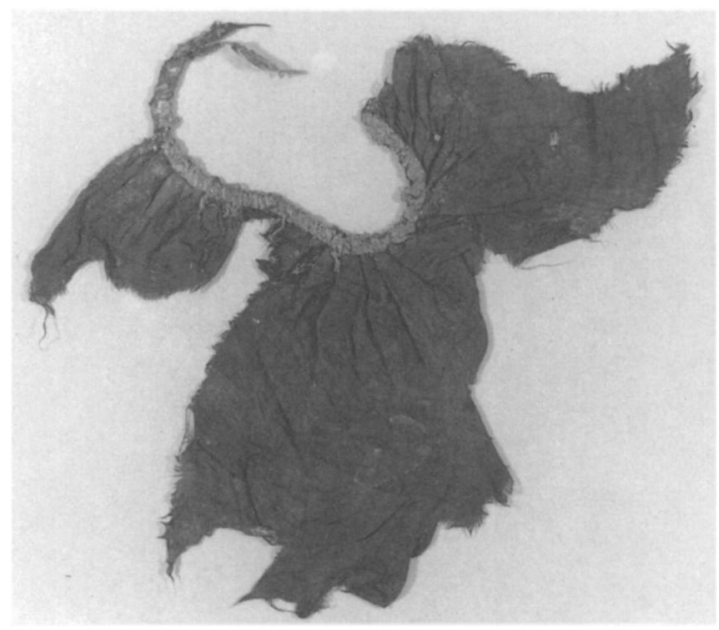

FIGURE 5. Silk pieces joined by a binding; possibly sections of a sleeve, fragment $6851 / 38,129$.
A bobbin lace fragment made of 2-ply silk yarns is among the privy textiles (Figure 4). The narrow, scalloped edging could have trimmed a man's, woman's, or child's inner or outer garment. Lace also signified rank. Earlier sumptuary laws in the Massachusetts Bay Colony prohibited everyone from wearing lace, but later in the century, small amounts of lace decorated shifts, shirts, aprons, or caps with little objection (Trautman 1989:52).

\section{Evidence of Garment Construction}

The silk fabrics show more evidence of having been sewn into garments than the other groups of fragments. A woven-silk binding is folded down the center with edges turned to the inside; the fabric that it bound, perhaps of a cellulosic fiber such as linen or cotton, is missing. Another binding holds several pieces of silk together in a shape that resembles the lower edge of a sleeve (Figure 5). A seam connects two of the pieces while other sections show evidence of seams along their edges. The direction of warp and weft yarns in the pieces resembles the grainline used on full sleeves in later centuries (Arnold 1972).

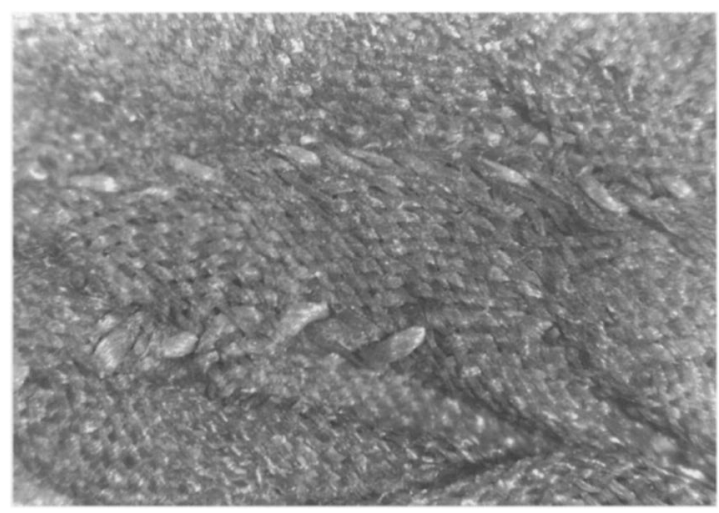

FIGURE 6. Double-stitched seam connecting two parts of the sleeve, fragment $6851 / 38,129$. 


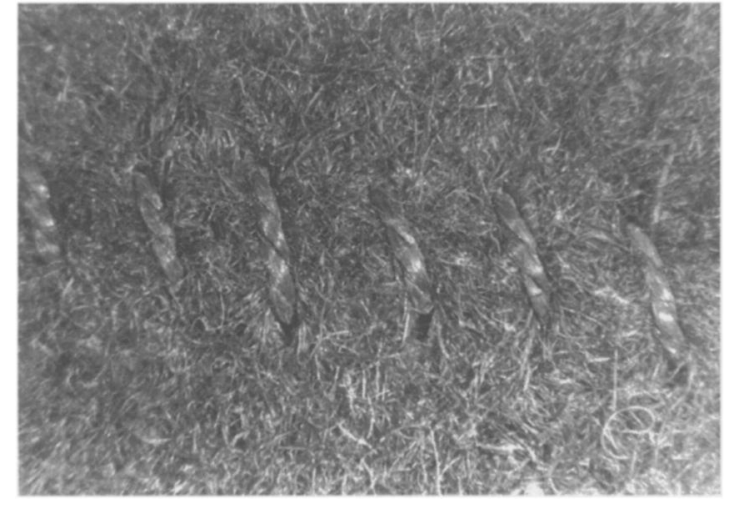

FIGURE 7. Butted seam in fulled wool sewn with silk thread in an oversewing stitch, fragment $6647 / 38,123 B$.

Evidence of garment construction in the privy fragments is quite valuable. Few extant garments remain, and fragments from other 17 th-century sites yield almost no information about types of seams, edge finishes, methods of controlling fullness, or decorative stitching. Examples of all these exist in the privy textiles.

Three types of seams appear in wool and silk fragments. Plain seams and a raised seam are made with running stitches (Morrell n.d.)(Figure 6). The raised seam started as a plain seam; then the seam allowances were pressed to one side, and a row of top stitching held them in place. Butted seams, created by joining raw

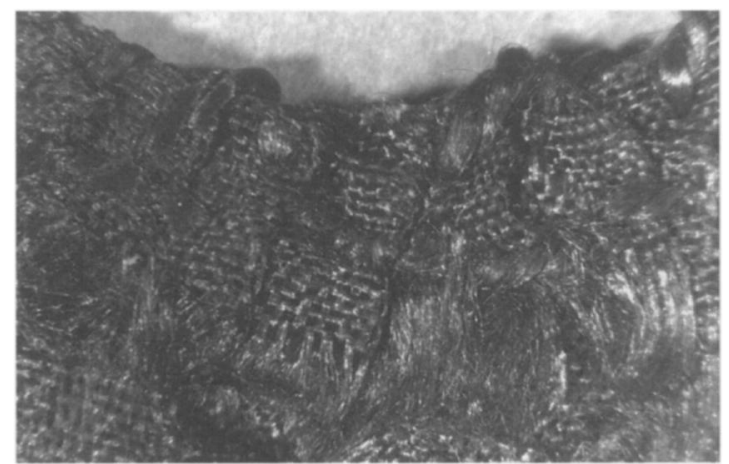

FIGURE 8. Pleats in plain, balanced weave silk sewn with 2-ply silk thread, fragment 6640/38,018D. edges, occur on four wool and silk fragments (Figure 7). The butted seams all have similar oversewing stitches that vary in closeness and direction of stitch (Grimm 1993:30).

Besides the edge bindings discussed earlier, hems also finished edges. Ten wool and silk fragments have narrow hems along one or more edges. In most the edges are turned twice. One edge is turned three times, and one is a rolled hem. Most of the hems are sewn with a hemming stitch; three have an overcast stitch that encircles the hem (Grimm 1993:21, 28).

As in Figures 5 and 8, sewers used pleating to control fullness in garments; no gathering techniques appear in any of the fragments. Slashing or cutting an outer layer of fabric to expose an underneath layer was becoming outdated, but a few silk fragments have cut slits that could have been slashes.

Only silk sewing threads survived conditions in the privy. A total of 19 threads are attached to fabrics; 16 are not. All but one of the sewing threads are 2-ply, S-spin yarns (Figure 7). The direction in which fibers are spun into yarns or multiple yarns twisted into plies is designated as $\mathrm{S}$ or $\mathrm{Z}$, using the center section of the letter to indicate direction. Diameters range from $0.3 \mathrm{~mm}$ to $1.5 \mathrm{~mm}$. The one complex yarn in the privy

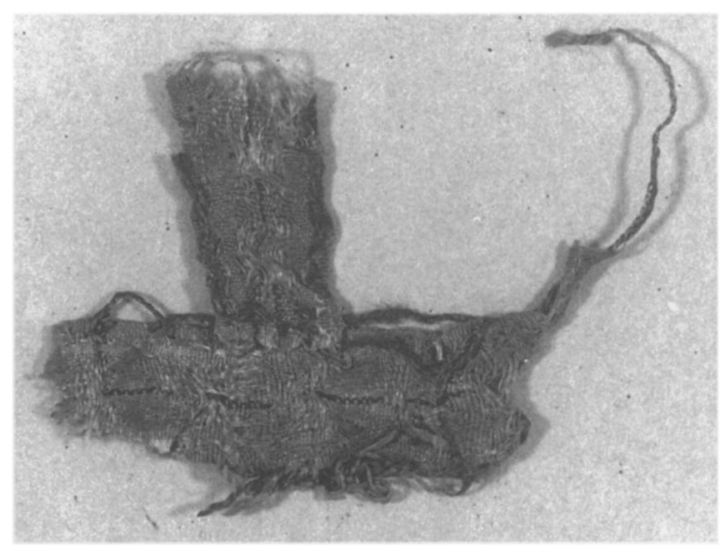

FIGURE 9. Two silk, 3-color patterned ribbons sewn at right angles with a decorative metallic yarn sewn to the lower edge, fragment 6660/38,031C. 


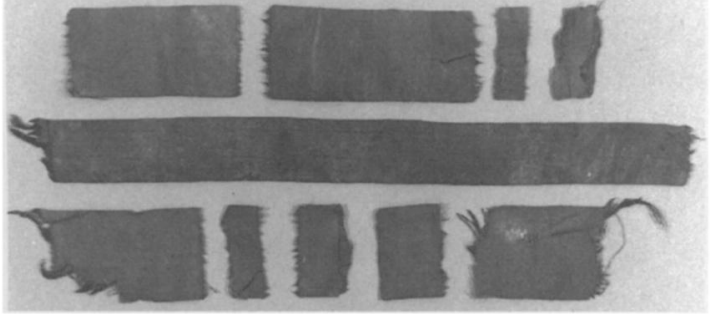

FIGURE 10. Examples of silk-taffeta ribbons, fragments $6863 / 38,132$.

fragments was a decorative yarn sewn to an edge of the ribbons in Figure 9. This rich trim has a narrow metal strip wrapped in a Z-direction around a silk core yarn.

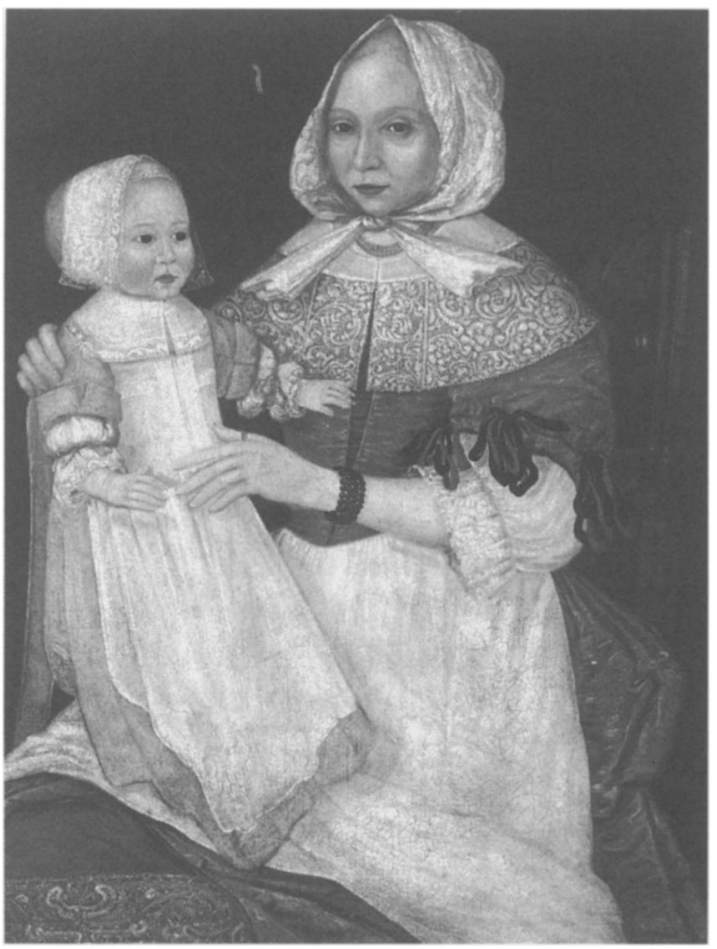

FIGURE 11. Mrs. Elizabeth Freake and baby Mary, 16701674. Depicts hood, red and black ribbons, lace, green silk dress fabric, and red wool petticoat with metallic threads (Courtesy of the Worcester Art Museum, Worcester, Massachusetts, gift of Mr. \& Mrs. Albert W. Rice)
Silk Ribbons

A total of 36 silk ribbon fragments have 22 different constructions or widths (Figure 10).

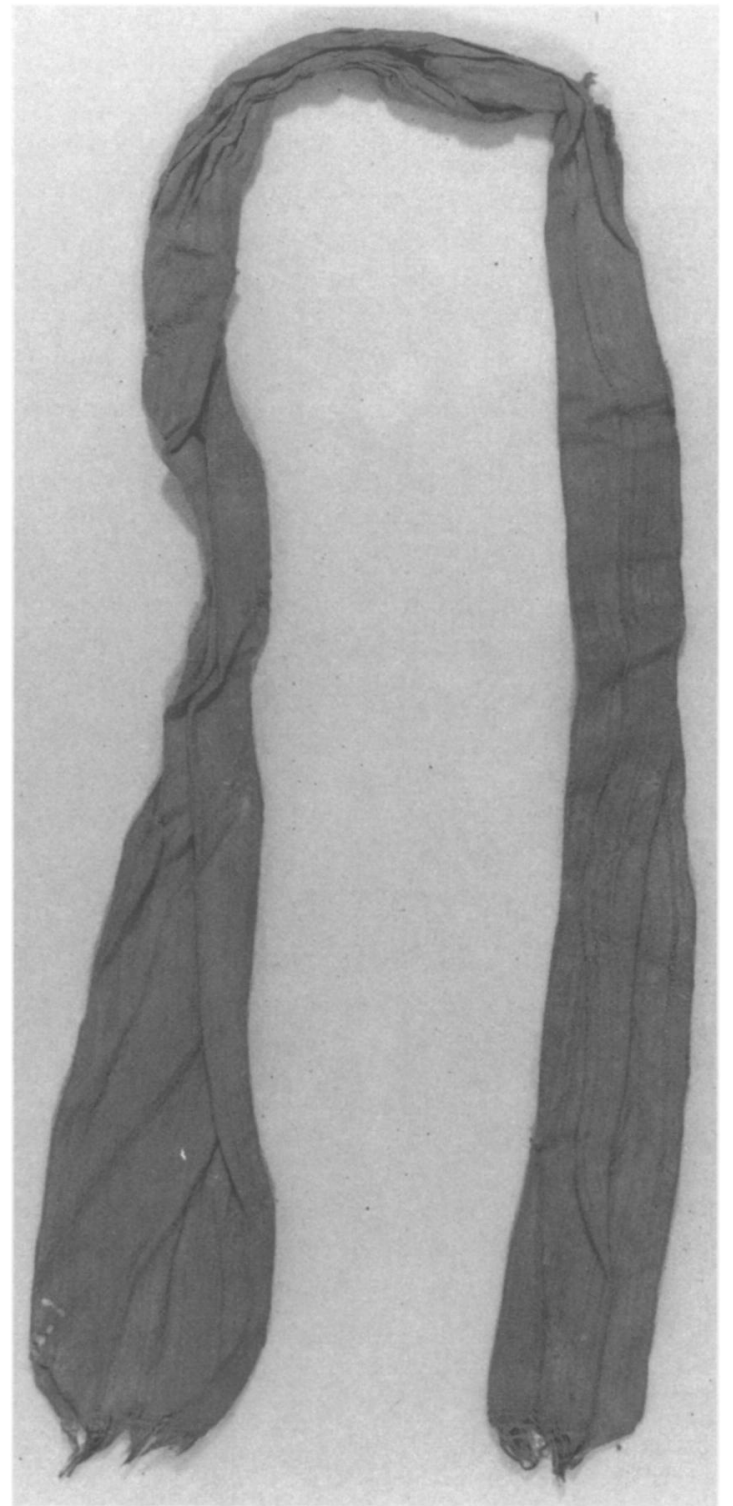

FIGURE 12. Silk-taffeta ribbon, possibly from a shoe, fragment $6824 / 38,128$. 
Many are taffeta, but those with a more prominent rib are called grosgrain. The widths vary from $0.8 \mathrm{~cm}$ to $5.0 \mathrm{~cm}$, but the majority measure between $1.0 \mathrm{~cm}$ and $2.0 \mathrm{~cm}$. The lengths can best be described as short. Of the 36 ribbon pieces, 30 are less than $13 \mathrm{~cm}$ in length. Contrary to the woven silk textiles in which fragments have degraded or pulled apart in irregular shapes, most of the ribbons have smooth, cut edges indicating that these pieces could be scraps since they show no evidence of having been sewn to anything.

Fashion followers in the 17th century used ribbons everywhere to decorate shoulders, tie sleeves, close shoes, encircle hats, or join collars (Figure 11). Some of the Boston ribbon fragments show evidence of use through folds and wrinkles. The longest ribbon $(47.7 \mathrm{~cm})$ is crumpled through the center section as if it had been used in a shoe (Figure 12); another (14.4 $\mathrm{cm}$ ) has many length-wise folds possibly from being bunched into a knot; and one has a loop knotted in it and is the appropriate width for a bodice lacing.

Ribbons of complex constructions include one with a satin stripe, four figure weaves, and one unusual float weave (Emery 1993:116-117)(Figure 13). The two patterned ribbons sewn together at right angles in Figure 9 probably trimmed a gar-

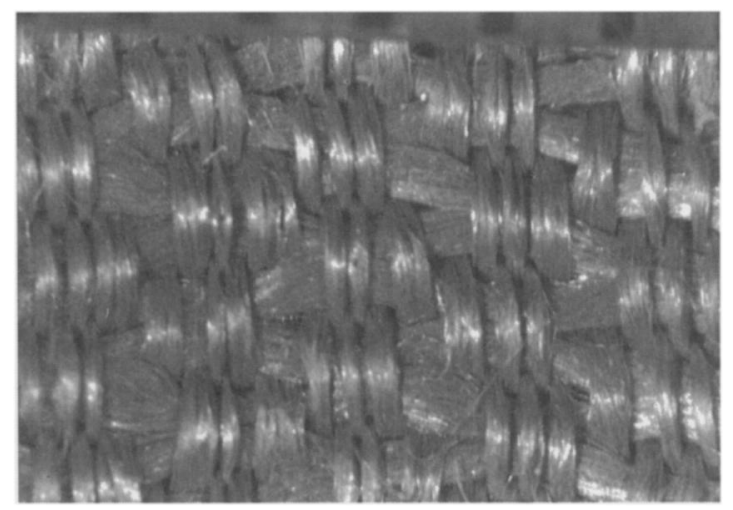

FIGURE 13. Silk ribbon, unusual float weave, fragment $6660 / 38,031 \mathrm{~B}$.

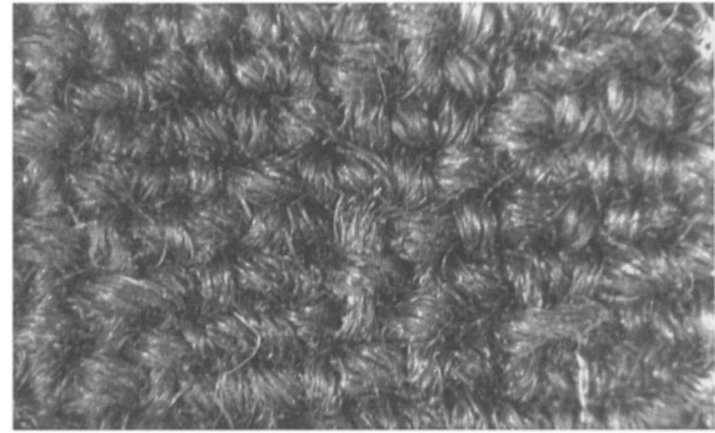

FIGURE 14. Fine, plain-weave wool fabric, fragment 6654 / $38,024 \mathrm{~A}$.

ment.

English manufacturers used prime, thrown silk imported from Italy to make silk ribbons and wider fabrics (Kerridge 1985:126). The combination of silk filaments and satin or complex weaves places such textiles on the high-quality end of the range of 17th-century cloths. In Boston and Suffolk County merchants' records quantities of imported silk fabrics ranked after those of wool, linen, and cotton (Baumgarten 1975:230-233).

\section{Wool Fabrics}

The environment of the privy favored the preservation of proteinaceous fibers; almost all of the fabrics were of silk and wool. Identification of wool was easy since conditions in the privy had not eroded the scales on the fibers as in New England Native American burials of the same period (Welters et al. 1996:213).

Like the silk textiles, the 13 wool fabrics in the privy also are indicative of status. Fabrics such as duffle, a common Native American trade cloth, were much coarser than the Boston privy wools which include sophisticated fabrics that the vast English wool industry had developed a century earlier (Figure 14). These light, soft fabrics, called New Draperies, contained fine worstedwool yarns sometimes mixed with silk (Mont- 
gomery 1984:309). English sheep of the period produced much coarser fibers than are used in the 20th century. Manufacturers obtained fine wool yarns either by importing wool from the Spanish who had bred Merino sheep for fine-diameter fiber or by combing out the short, coarse fibers to make worsted yarns (Kerridge 1985:13).

Norwich, England, was famous for marketing the New Draperies (Montgomery 1984:309). Camlet is perhaps the best known of these fabrics. Richard Smith, Jr.'s, camlet cloak at the Rhode Island Historical Society is one of the few 17th-century garments from New England to have survived the centuries intact. Boston merchants (Baumgarten 1975:230) imported camlets of several varieties. Most likely, some of the plain-weave wool textiles from the privy are camlets because of their high yarn counts and worsted yarns. Some of the twill weave wools probably were known as serge; the diagonal line created by a progression of floating yarns identifies them as twills.

Other wool fabrics from the privy have quite large yarns, which combined with extensive fulling make a very compact fabric as the one in Figure 7. Fulling is a finish that shrinks the fabric, obscuring the woven structure. The privy's fulled wools are much thicker than those from 17th-century burials of the Narragansett In-

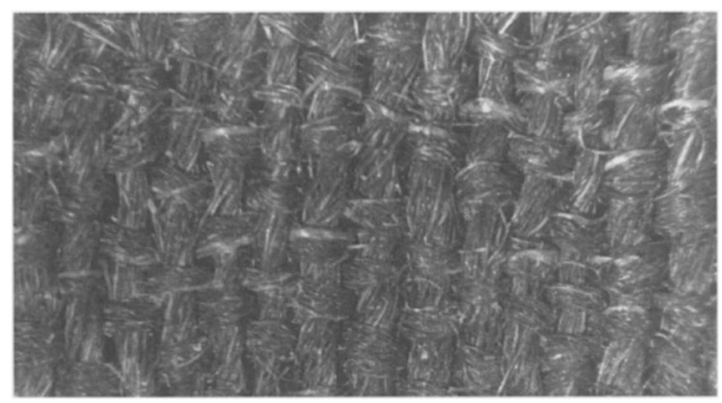

FIGURE 15. Rare mixture made of 2-ply yarns-a lightcolored single silk yarn and a single wool yarn spun together, fragment $6647 / 38,122$. dians in Rhode Island and the Mashantucket Pequot Indians in Connecticut (Welters 1985, Ordoñez et al. 1991). The heaviest fulled plain weave from the privy is $1.2 \mathrm{~mm}$ thick; the greatest thickness for twills is about $2.0 \mathrm{~mm}$. These could have been for outdoor wear such as cloaks and hoods.

Some of the fulled wool fragments have cleancut edges, but these straight edges are not sufficient to suggest that someone was tailoring wool garments at home. The thickness of fulled wools prevented the fabric from being folded into hems or plain seams. Butted seams as in Figure 7 joined pieces at seamlines. Since the fulled fabric did not ravel, tailors left cut edges unfinished along the outer perimeters of garments, a practice that continued into the 19 th century. The straight-cut edges could be sections of seams and edges that did not degrade.

\section{Mixtures}

Among the most unusual fabrics from the privy are those made of more than one fiber. These are called mixtures, fabrics in which yarns of different fiber contents are combined. Two fabrics have silk yarns in one direction and wool in the other. Two other silk-wool mixtures have an unusual yarn not seen often in historic fabrics (Figure 15). Warp and weft yarns are made from a single silk yarn and a single wool yarn spun together into a ply. Such a plied yarn, made of unlike singles, is classified as a spiral or corkscrew yarn. Wool-silk mixtures would have had a feel and drape different from other all-wool or all-silk fabrics-more body than silk fabrics but more subtle than wool. Production of these mixtures required very proficient spinners and weavers, and their price would have been well above fine all-wool fabrics.

Equally intriguing are four fabrics that looked like a group of pink and cream-colored, tangled yarns. Silk warp and weft yarns remain in groups of four or six with unfilled spaces between when the fabric is opened up as in Figure 
16. Crimps in the yarns floating across the unwoven spaces indicate that additional warp and weft yarns had once been part of the woven structure. The missing yarns could have been cellulosic-cotton or linen-degraded by the privy environment. These silk and cellulosic combinations were expensive fabrics like the silk and wool mixtures.

\section{Mineralized Cotton Fabrics}

Six plain-weave cotton fragments survived because they are partially mineralized. Mineralized textiles are called pseudomorphs-literally "false forms"-formed when mineral compounds replace the organic elements or when a cast is formed around the original textile fibers. Textile pseudomorphs are a rare phenomenon, but cotton pseudomorphs are even rarer than those of wool. Numerous wool pseudomorphs occurred in both Mashantucket Pequot and Narragansett burials (Coho 1993; Welters et al. 1996:219-221).

Cotton was a high-status fiber in the 17 th century. After the East India trade commenced around 1600 , a large variety of cotton cloths became available to Europeans. Merchants' records show they were imported into Boston in the second half of the 17th century (Baumgarten 1975:230-233). Cotton calico was used for men's and boys' shirts and drawers plus women's and girls' shifts although linen was much more common for innerwear of all classes (Trautman 1989:55, 58-59, 61). No linen fabrics survived in the privy. Cotton fabrics also survived in the Narragansett Indian site (Welters et al. 1996:222). The yarn sizes and yarn counts of those are quite similar to the mineralized Boston cotton, but the direction of spin differs.

\section{Mineralized Bast-fiber Yarns}

Two yarns of bast fibers such as hemp or jute survived due to partial mineralization. The fiber bundles had not separated into individual fiber, or ultimates, when the mineralization process began coating the surfaces, creating negative

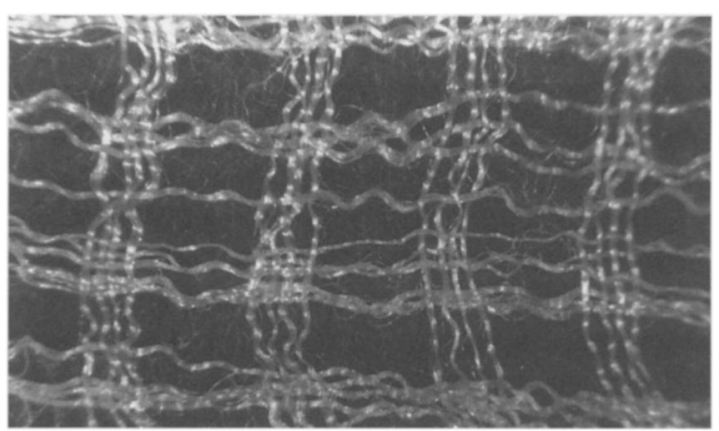

FIGURE 16. Fabric of pink and cream silk yarns with spaces created by missing cellulosic yarns, fragment $6540 / 38,110$.

pseudomorphs. Even with the coating, the 2-ply yarns with a Z-spin are visible. The yarn diameters $(2.9 \mathrm{~mm}$ and $3.0 \mathrm{~mm}$ ) are typical for twine. In most North American and northern European archaeological sites, only stitch marks remain where linen sewing threads once held wool pieces of garments together. Exceptions include these bast yarns found alone and others in shoe soles from the Boston privy plus North American bast fibers of Indian hemp in Pequot and Narragansett sites (Welters and Ordoñez 1995).

\section{Discussion and Conclusion}

An abiding question concerning the privy fragments is why the fabrics were in the privy. Speculations include accidental and purposeful deposition. Worn-out or unwanted garments or accessories could have been discarded. Broken shoe or hood ribbons might have been dropped in the privy. Perhaps in 1672 Katherine threw her errant husband's clothes and shoes in the privy rather than sending them to him in Pemaquid as he requested by letter (Superior Court of Suffolk County 1672:63).

Clothing believed to be contaminated from diseased individuals could have been disposed of in the privy. Wool, silk, and cotton fabrics might have been used for household cleaning rags, but less expensive linen cloths are more probable; 
therefore, this is not a likely source of the fragments. Did someone in the household retrim clothes or hoods with new ribbons? Strips with cut ends support this theory since many of the ribbon fragments have clean-cut ends and retrimming was common. The few pins and the ribbon scraps are not sufficient evidence to support dressmaking or tailoring as an occupation in the home.

Accidentally dropping garments or accessories in the privy is a very plausible speculation. Adults or children, especially unsupervised ones, could knock or drop an item into the hole in the privy house. This is a probable explanation considering the number of children in the family and the number of expensive fabrics that normally would not be thrown away.

In general, the types of fabrics in the privy are indicative of a family of "gentle" status. The 17 th century was one of the most excessive in costume history and has been termed the century of ribbons, bows, and lace. Throughout most of the century, the Massachusetts Bay Colony regulated dress through sumptuary laws, which attempted to moderate excessive fashions and prevent servants and laborers from wearing the trappings of the gentry. The first law was passed in 1634 , then re-enacted and expanded numerous times. In 1651 the General Court divided society into those with estates valued above $£ 200$ and those under $£ 200$ (Fischer 1989:141-143; Trautman 1989:52-53).

Specific articles of cloth, fabrics, and trims were allowed persons of high standing. The privilege of wearing gold or silver lace and buttons, points (ties) at the knee, great boots, and new fashions was accorded to gentlemen. Gentlewomen were allowed silk and tiffany hoods, scarves, bone lace costing above two shillings per yard, and new fashions. Court records in Cambridge, Massachusetts reveal that wearing silk hoods by women of lower rank was one of the most frequent offenses along with the "addition of superfluous ribbons, both on hair and apparel" (Trautman 1989:53). Evidence of many of these fashions came from the Cross Street privy, which has provided unparalleled examples of 17 th-century textiles and costumes.

These unique textiles exemplify urban life in Colonial New England. The fragments of silk fabrics and ribbons, wools, mixtures, and mineralized cellulosics plus evidence of sewing techniques give 20th-century viewers a glimpse of a fashionably dressed Boston family of 300 years ago. Their apparel from head to toe is represented in these fabrics for hoods, dresses, underclothes, coats, breeches, and stockings.

\section{ACKNOWLEDGMENTS}

We thank Michael Roberts and Martin Dudek of Timelines, Inc., for their help and support during the analysis. Tora Sterregaard, graduate student at the University of Rhode Island, aptly characterized each of the textile fragments and prepared the data sheets.

\section{REFERENCES}

\section{ARNOLD, JANET}

1972 Patterns of Fashion 1: Englishwomen's Dresses \& Their Construction, 1660-1860. Drama Books Specialists, New York.

\section{BAUMgarTEN, LiNDA}

1975 The Textile Trade in Boston, 1650-1700. In Arts of the Anglo-American Community in the Seventeenth Century, edited by Ian M. Quimby, pp. 219-273. University Press of Virginia, Charlottesville.

Соно, СатнY

1993 Textile Pseudomorphs from Seventeenth-Century New England Native American Burials. The American Institute for Conservation, Textile Specialty Group Postprints 6:70-78.

EMERY, IRENE

1993 The Primary Structures of Fabrics: An Illustrated Classification. The Textile Museum, Washington.

FisCher, DAVId HACKeTt

1989 Albion's Seed: Four British Folkways in America. Oxford University Press, Oxford, England.

Grimm, Martha WinsLow (COMPILER)

1993 The Directory of Hand Stitches Used in Textile Conservation. Textile Conservation Group, New York. 
KeRrIDGE, ERIC

1985 Textile Manufactures in Early Modern England. Manchester University Press, Manchester, England.

Montgomery, FLoRenCe M.

1984 Textiles in America, 1650-1870. W. W. Norton, New York.

MoRrell, ANNE

n.d. The ATN Guide to Structural Sewing: Terms and Techniques. Manchester Polytecnic, Manchester, England.

Ordoñez, Margaret T., Linda Welters, and Kathryn

TARLETON.

1991 Analysis of Textiles from Long Pond Site. Submitted to the Public Archaeology Survey Team, University of Connecticut, Storrs.

Ordoñez, Margaret T., and Linda Welters

1995 Central Artery/Tunnel Project Textiles. Submitted to Timelines, Inc., Littleton, MA.

SuPerior Court of Suffolk County

1672 Letter from Edward Naylor to Katherine Nanny Naylor, Pemaquid, 24 June. Manuscript, Superior Court of Suffolk County 12:63, Massachusetts State Archives, Boston.

Trautman, Patricia.

1989 Dress in Seventeenth-Century Cambridge, Massachusetts: An Inventory-Based Reconstruction.
In Early American Probate Inventories, edited by Peter Benes, pp. 51-71. Dublin Seminar for New England Folklife Annual Proceedings 1987. Boston University Scholarly Publications, Boston.

WeLTERS, LINDA

1985 Narragansett Bay Survey: Conservation and Analysis of European Textiles from RI-1000. Submitted to the Rhode Island Historic Preservation Commission, Providence.

Welters, Linda, ANd Margaret ORdoñez

1995 Indian Hemp. Presentation at Plants and People, Dublin Seminar for New England Folklife, Deerfield, MA.

Welters, Linda, Margaret Ordoñez, Kathryn

TARLETON, AND JOYCE SMITH

1996 European Textiles from Seventeenth-Century New England Indian Cemeteries. In Historical Archaeology and the Study of American Culture, edited by Lu Ann De Cunzo and Bernard L. Herman, pp. 193-232. Henry Francis DuPont Winterthur Museum, Winterthur, DE.

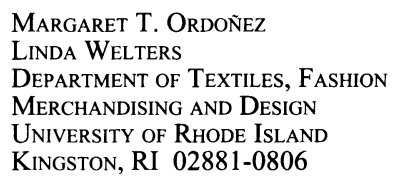

MARgaret T. ORDOÑEZ

Department of Textiles, Fashion

UNIVERSITY OF RHODE ISLAND

KINGSTON, RI 02881-0806 